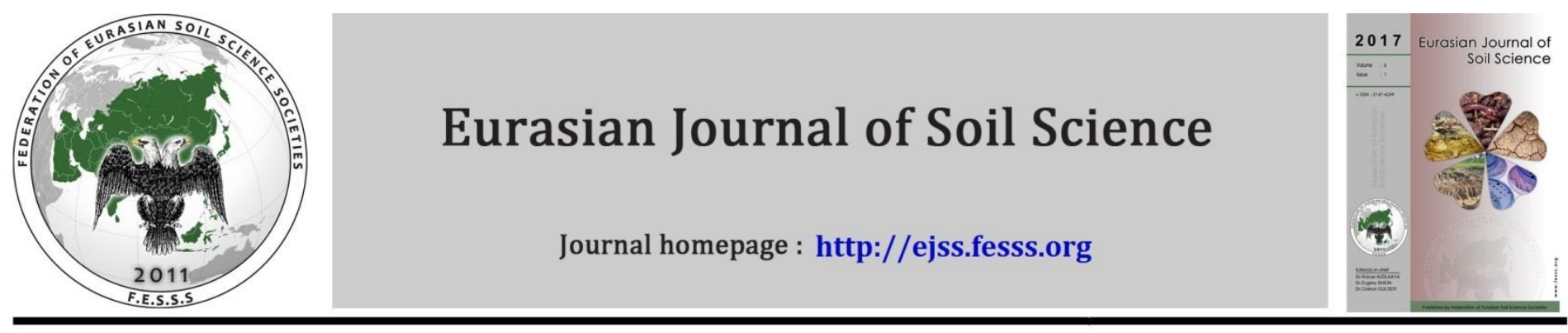

\title{
Enzyme activity of Chromic Luvisols under different degree of erosion and land use
}

\author{
Kostadinka Nedyalkova *, Radka Donkova, Darina Deribeeva
}

N. Poushkarov Institute of Soil Science, Agrotechnologies and Plant Protection, Sofia, Bulgaria

\begin{tabular}{ll}
\hline & Abstract \\
& Soil erosion is a serious environmental problem and a threat to the sustainable \\
agriculture production. Little information is available on enzyme activities of eroded \\
soils in Bulgaria, especially on their relations to the degree of erosion and soil \\
properties. In this work, slightly, moderately and severely eroded Chromic Luvisols \\
under different land use (pasture, crop field and virgin) were studied. Enzyme activities \\
(invertase, catalase and phosphatase), total nitrogen, total carbon, available \\
phosphorus contents and soil particle distribution were determined and possible \\
relations between them were examined. Data showed that enzyme activities tended to \\
lower with increasing the degree of erosion. This was better pronounced for invertase \\
and phosphatase in pasture and virgin soils. Depending on land use, all enzyme \\
activities decreased in the order pasture > virgin > crop field soils, showing positive \\
impact of soil cover and negative effect of cultivation practices. Soil invertase and \\
phosphatase activities were in close relations with soil carbon content. The activities of \\
catalase and phosphatase correlated positively with soil clay. Invertase only was in \\
positive relation with soil silt and in negative relation with the sand content. Data \\
obtained are intended to contribute to development of biological indicators of eroded \\
soils.
\end{tabular}

Keywords: Enzymes, eroded soils, degree of erosion, land use, soil properties.

(C) 2017 Federation of Eurasian Soil Science Societies. All rights reserved

\section{Introduction}

Soil erosion is a threat to the environment and sustainable agriculture development. Due to loss of top soil the structure, air and water regime of soils are getting worse and nutrients are lost. As a result, the fertility and productivity of eroded soils often decline (Lal, 2006).

Soil enzymes play essential role in maintaining soil fertility. They catalyze biochemical reactions involved in organic matter decomposition, nutrient cycling and element transformation thus releasing plant available nutrients. They respond quickly and sensibly to changes in soil environment. Enzyme activities are considered in monitoring and assessing the soil status and quality. They are proposed as suitable biological indicators for evaluation of soil alterations in natural and agro-ecosystems (Trasar-Cepeda et al., 2000; Puglisi et al. 2006; Acosta-Martinez et al., 2007).

Various aspects of erosion impact on enzyme activities in soils of different type and usage had been investigated. Park et al. (2014) reported that enzyme activities tended to decrease in eroded Alpine grassland soils under intense agricultural activities (grazing and hay harvesting). Enzymes ( $\beta$-glucosidase,

\footnotetext{
${ }^{*}$ Corresponding author.

N. Poushkarov Institute of Soil Science, Agrotechnologies and Plant Protection, 1080 Sofia, Bulgaria

Tel.: +35928246141

E-mail address: nedyalkova.k@gmail.com 
$\mathrm{N}$-acetyl glucosamidase, phosphatase and arylsulfatase) correlated positively with soil carbon and nitrogen concentrations.

Studying soils affected by different levels of erosion, Moreno-de las Heras (2009) found that erosion had greatly influenced the processes related to soil physical and biological functionality. Significant decreasing trends in aggregate stability, microbial activity and enzyme activities (phosphatase, $\beta$-glucosidase and urease) along the erosion gradient were found. The impact of organic matter and clay content on soil structure formation and microbial and enzymatic activities was proved.

Kizilkaya et al. (2003) found significant correlation between acid phosphatase activity and soil erodibility indices in soils from Black Sea region. Yin et al. (2014) used enzyme activity as one of the indicators of revegetation effect on severely eroded red soil. Authors reported that re-vegetation improved soil enzyme activities compared with bare eroded soil. All enzymes studied ( $\beta$-glucosidase, invertase, cellulase, acid phosphatase, polyphenoloxydase and urease) correlated with soil organic carbon and total nitrogen contents.

Information on enzyme activities of eroded soils in Bulgaria is scarce. Little is known about their relations to soil properties and the degree of erosion. The present work aimed to describe changes in enzyme activities, chemical and physical properties of Chromic Luvisols depending on the degree of erosion and land use, and to find out any relationships between them.

\section{Material and Methods}

\section{Soil sampling}

Samples from 0-20 cm soil layer of eroded Chromic Luvisols (FAO legend) located in Sofia plane (Bulgaria) were collected. Pasture soils, crop field soils under conventional agriculture and virgin soils, differing in the degree of erosion were included in this study. Sample description and numbering are shown in Table 1. Soils under different degree of erosion within each land use group and between the three groups studied were compared for enzyme activities, chemical and physical properties.

Table 1. Chromic Luvisols sample description

\begin{tabular}{ll}
\hline Land use & \multicolumn{1}{c}{ Sample №, degree of soil erosion, plant cover } \\
\hline \multirow{2}{*}{ Pasture } & $\mathbf{1}$ - slightly eroded, grasses \\
& $\mathbf{2}$-moderately eroded, grasses \\
\hline \multirow{2}{*}{ Crop field; conventional agriculture } & $\mathbf{3}$ - non-eroded, stubble \\
& $\mathbf{4}$ - moderately eroded, corn \\
& $\mathbf{5}$ - moderately eroded, wheat \\
\multirow{2}{*}{ Virgin soils } & $\mathbf{6}$ - slightly eroded, meadow \\
& $\mathbf{7}$ - moderately eroded, meadow \\
& $\mathbf{8}$ - severely eroded, meadow \\
\hline
\end{tabular}

\section{Enzyme activities and analyses}

Three enzymes - invertase, catalase and acid phosphatase, known to participate in important biochemical processes in soil were studied. Soil invertase (EC 3.2.1.26) is involved in the carbon cycle. It plays catalytic function in the hydrolysis of sucrose - one of the most abundant plant soluble sugars. Invertase activity was determined by modified Hoffman's method (Ampova and Paskaleva, 1970) and results were expressed as $\mu \mathrm{g}$ glucose $\mathrm{g}^{-1} \mathrm{~h}^{-1}$.

Catalase (EC 1.11.1.6) decomposes hydrogen peroxide formed during respiration and organic matter oxidation thus preventing cells from damage caused by molecular oxygen released. Catalase activity was determined by $\mathrm{KMnO}_{4}$ titration according to Stefanic and Dumitru (1970) and data were presented as mg $\mathrm{H}_{2} \mathrm{O}_{2} \mathrm{~g}^{-1} \mathrm{~h}^{-1}$.

Soil phosphatases (EC 3.1.3) hydrolyze organic phosphorus compounds in soil and release free phosphate ions for plant nutrition. They take part in phosphorus cycling. Phosphatases are among the most commonly studied enzymes as indicators of soil alteration (Puglisi et al., 2006). In this study we measured acid phosphatase (EC 3.1.3.2) activity using the assay of Tabatabai (1994). Results were presented as $\mu \mathrm{mol} \mathrm{p-}$ nitrophenol g-1 $\mathrm{h}^{-1}$. 
Fresh soil samples were stored in refrigerator at $4^{\circ} \mathrm{C}$. Before analyzing they were processed through 2-mm sieve and root fragments were removed. Assays were performed in triplicates.

\section{Chemical and physical analyses}

Air dried soil was sieved through 2-mm mesh and samples were analyzed for total carbon (C) (method of Tyurin (Arinushkina, 1975)), total nitrogen (N) (Kjeldahl's digestion procedure), and available phosphorus (P) (Ivanov, 1984) contents. Soil reaction $(\mathrm{pH})$ was determined in 1:2.5 soil/water suspension using potentiometer. Mineral particles content - sand (1.0-0.25 mm and 0.25-0.05 mm particle size fractions), silt (0.05-0.01 $\mathrm{mm}, 0.01-0.005 \mathrm{~mm}$ and $0.005-0.001 \mathrm{~mm}$ size fractions) and clay ( $<0.001 \mathrm{~mm}$ size-fraction), was determined by wet sieving according to the method of Kachinskiy (1968).

\section{Statistical analyses}

Data were processed by ANOVA and mean values were compared by Dunkan's test at $\mathrm{P}<0.05$. Relationships between enzyme activities and soil properties were assessed by correlation analysis.

\section{Results}

Chromic Luvisols studied were characterized by sandy loam texture, medium acid reaction and medium level of humus content. Among samples, soil properties differed depending on the degree of erosion and land use.

\section{Enzyme activities}

Within each land use group of soils, enzyme activities tended to decrease in soils subjected to higher degree of erosion. Soil invertase activity lowered in moderately eroded pasture soil, in moderately eroded crop field soil under corn and in severely eroded virgin soil. Catalase activity decreased in moderately eroded crop field soil under corn. Phosphatase activity decreased in moderately eroded pasture soil, and in moderately and severely eroded virgin soils (Figure 1).

In general, the highest enzyme activities were recorded in pasture soils, followed by virgin and crop field soils which was confirmed for the three enzymes studied.

\section{Soil chemical properties}

Total carbon and total nitrogen contents lowered with increasing the degree of soil erosion, as noticed for moderately eroded pasture and crop field soils and for moderately and severely eroded virgin soils (Figure 2). Available phosphorus content showed no changes within pasture and virgin soil groups. Among crop field soils, phosphorus lowered in moderately eroded soil under corn.

Soil pH had little variations among all samples, except the moderately eroded crop field soil under corn where $\mathrm{pH}$ noticeably lowered (Figure 2).

\section{Soil texture}

In moderately eroded pasture soil, silt content decreased (in $0.01-0.005 \mathrm{~mm}$-size and $0.05-0.01 \mathrm{~mm}$-size fractions), and in return sand (0.25-0.005 mm-size fraction) and clay contents increased. In moderately eroded crop field soils under wheat and under corn, silt and clay contents decreased, and in response sand content considerably increased. In moderately and severely eroded virgin soils silt content decreased (considerably in $0.01-0.005 \mathrm{~mm}$-size fraction), clay content slightly lowered and sand content considerably increased (Figure 3).

\section{Relationships}

Soil invertase activity correlated positively with soil total carbon and silt contents and negatively with soil sand (Table 2). Catalase activity correlated positively with soil clay content and with invertase and phosphatase activities, as well. Soil phosphatase was in positive correlations with soil total carbon and clay contents. Concerning all soils studied, no correlation between erosion degree and enzyme activities was found (Table 2). In particular, phosphatase correlated negatively with the degree of erosion ( $r=-0.847)$ in virgin soils group. 


\begin{tabular}{lccc}
\hline \multicolumn{4}{l}{ Table 2. Correlation coefficients (r) between enzyme activities and properties of the Chromic Luvisols studied } \\
\hline Soil properties & Invertase & Catalase & Phosphatase \\
\hline pH & 0.668 & 0.502 & 0.156 \\
$\mathrm{C}$ & $0.713^{*}$ & 0.549 & $0.726^{*}$ \\
$\mathrm{~N}$ & 0.556 & 0.410 & 0.670 \\
$\mathrm{P}$ & 0.388 & 0.546 & 0.152 \\
Sand $(1.0-0.25 \mathrm{~mm})$ & $-0.830^{*}$ & -0.663 & -0.538 \\
Sand $(0.25-0.05 \mathrm{~mm})$ & -0.524 & -0.111 & -0.212 \\
Silt $(0.05-0.01 \mathrm{~mm})$ & $0.766^{*}$ & 0.460 & 0.369 \\
Silt $(0.01-0.005 \mathrm{~mm})$ & 0.538 & 0.097 & 0.255 \\
Silt $(0.005-0.001 \mathrm{~mm})$ & 0.548 & 0.148 & -0.273 \\
Clay $(<0.001 \mathrm{~mm})$ & 0.522 & $0.725^{*}$ & $0.719^{*}$ \\
Degree of erosion & -0.094 & 0.025 & -0.105 \\
Invertase & & $0.792^{*}$ & 0.631 \\
Catalase & & & $0.844^{* *}$ \\
\hline
\end{tabular}

Significant at: ${ }^{*}$ - $\mathrm{P}<0.05$; ${ }^{* *}$ - $\mathrm{P}<0.01$
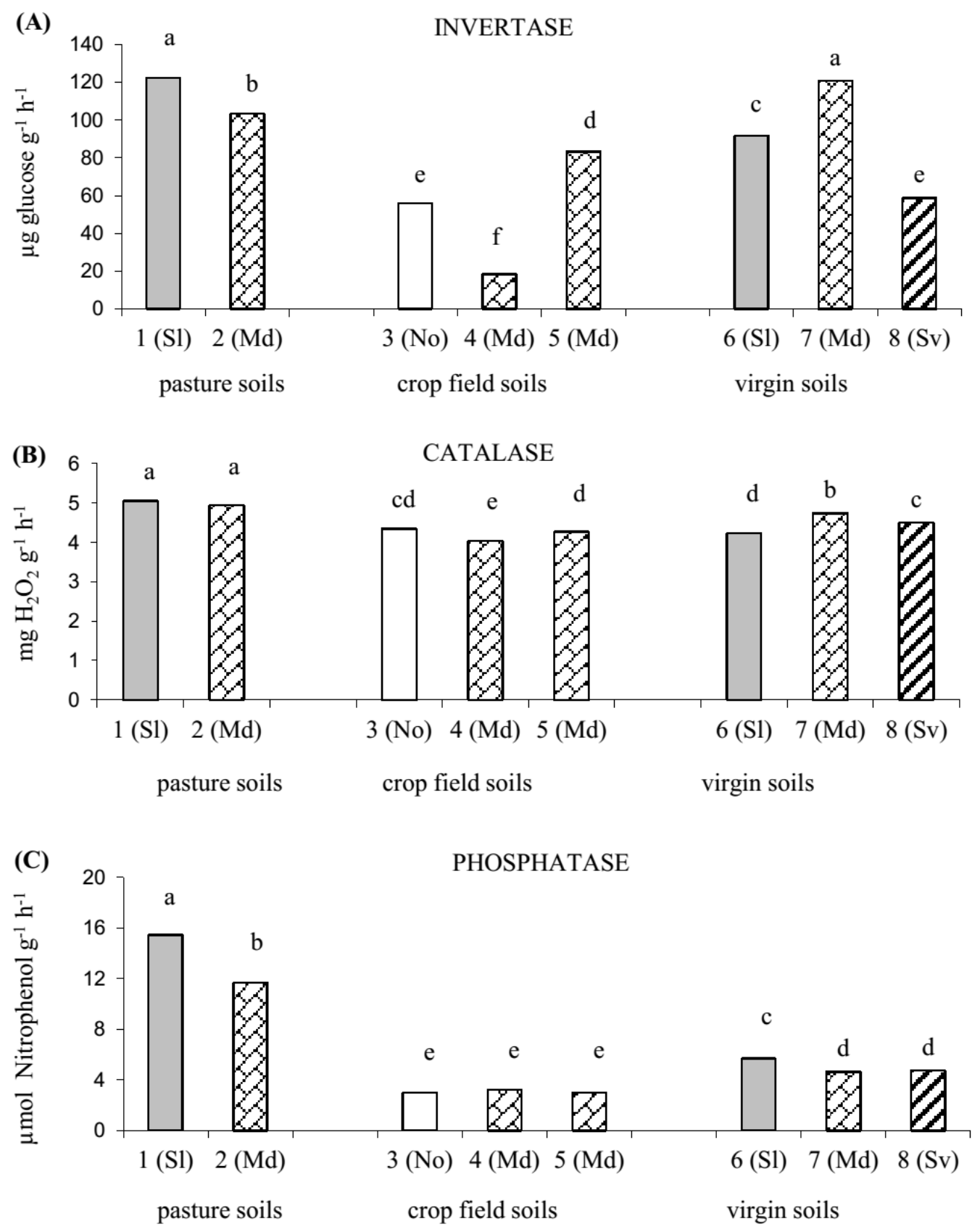

Figure 1. Invertase (A), catalase (B) and phosphatase (C) activities of slightly eroded (SI), moderately eroded (Md), severely eroded (Sv) and non-eroded (No) Chromic Luvisols under different land use. Different letters above bars show significant differences between values at $\mathrm{P}<0.05$ 

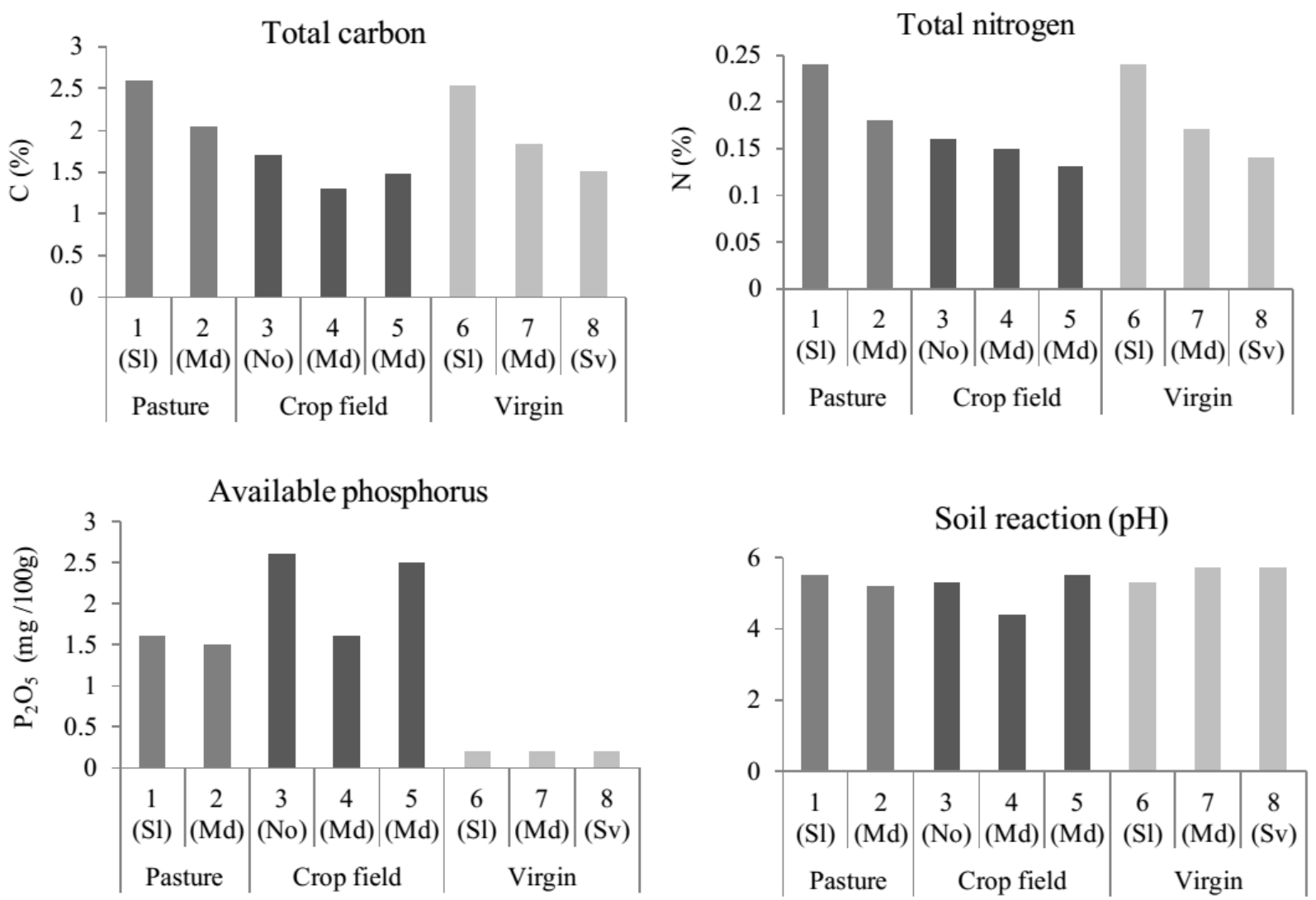

Figure 2. Soil chemical properties of slightly eroded (Sl), moderately eroded (Md), severely eroded (Sv) and non-eroded

(No) Chromic Luvisols under different land use

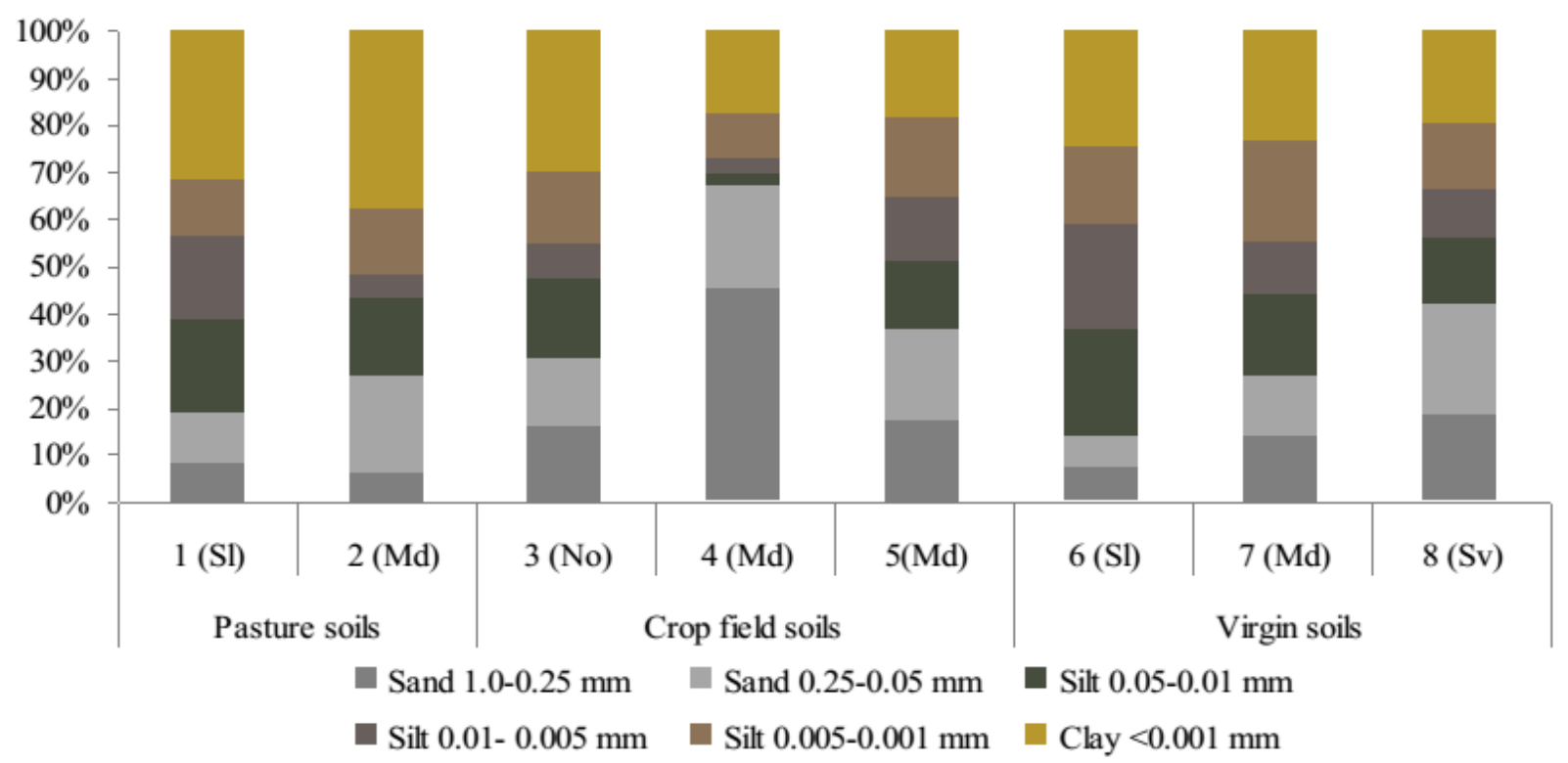

Figure 3. Soil texture of Chromic Luvisols studied: slightly eroded (Sl), moderately eroded (Md), severely eroded (Sv) and non-eroded (No) 


\section{Discussion}

Enzyme activities of Chromic Luvisols studied varied depending on the degree of erosion and land use type. They tended to lower with increasing the degree of erosion. This was better pronounced for invertase and phosphatase in pasture and virgin soils. In crop field soils, enzymes were influenced by crop plant, as well. Invertase and catalase activities decreased in the soil under corn, but increased in the soil under wheat when the degree of erosion increased.

Depending on the land use type, all enzyme activities decreased in the order pasture $>$ virgin $>$ crop field soils, showing positive impact of plant cover and negative effect of cultivation practices. Similarly, AcostaMartinez et al. (2007) reported on lower enzyme activity in agriculture comparing to pasture soils (noneroded ones).

Washing the top soil away, erosion usually causes loss of nutrients. In this study, a tendency of decreasing of total carbon and total nitrogen soil contents with increasing the degree of erosion within each land use soil group was found. The total carbon and nitrogen contents were lower in the non-eroded crop field soil compared to slightly eroded pasture and virgin soils which pointed the negative influence of crop cultivation practices. This also proved the well known protective function of grasses against soil erosion. Such effect of forages in improving aggregate stability and organic carbon content of a clay soil was shown by Gülser (2006). Available phosphorus content differed among the three groups of soils. In general, it was higher in pasture and crop field soils compared to virgin soils which was obviously due to soil amendments. They commonly improve soil nutrient status and structure. Özdemir et al. (2015) reported that organic and inorganic carbon sources improved the structure and decreased erodibility of an acid soil.

Due to erosion fine soil particles are commonly washed what results in increased sand content. In this study, soil texture tended to worsen in soils with higher degree of erosion. In moderately eroded crop field soils, the reduction of silt and clay contents was higher than that in moderately eroded pasture and virgin soils, indicating that crop field soils were more susceptible to erosion. This could be related to soil disturbance by tillage and lower root aggregation effect of crops compared to dense native vegetation.

Some relationships between enzyme activities and Chromic Luvisols properties were found. Soil invertase and phosphatase activities were in close relations with soil carbon. The results are in confirmation with data obtained by other authors. Marx et al. (2005) showed that activities of hydrolases studied positively correlated with organic carbon content in grassland silty clay loam soil. Similar correlations were reported by Park et al. (2014) and Yin et al. (2014), as cited before.

The positive correlations of catalase and phosphatase activities with soil clay and of invertase activity with soil silt we found, confirmed findings by other authors. Studying enzyme activities in soil particle size fractions, Kandeler et al. (1999) reported that invertase activity was mostly located in the silt fraction and that alkaline phosphatase activity was mainly registered in the silt and clay fractions of Haplic Chernozem. Authors showed that enzyme activities in particle-size fractions were mostly affected by the type of tillage. According to the study of Marx et al. (2005) phosphatase had the highest absolute activity in the clay-size fraction of grassland soil.

An effect of erosion gradient on virgin soils properties was noticed in our study. Carbon, nitrogen, silt and clay contents gradually decreased with increasing the degree of erosion, while sand content gradually increased. Particularly, phosphatase activity tended to decrease in virgin soils under higher degree of erosion. In our previous study (Nedyalkova et. al., 2013), negative correlation between phosphatase activity and the degree of erosion in virgin soils was reported.

\section{Conclusion}

A clear tendency of nutrients and texture loss with increasing the degree of erosion in crop field, pasture and virgin Chromic Luvisols was found. Negative effect of erosion gradient on virgin soils properties was noticed. Crop field soils were more susceptible to erosion. The protective function of grasses against erosion was shown, as well.

Enzyme activities decreased in the order pasture > virgin > crop field soils. Invertase and phosphatase activities tended to lower with increasing the degree of erosion in pasture and virgin soils. 
Relationships with soil properties differed for particular enzymes. Soil invertase and phosphatase activities were in close relations with soil carbon. Catalase and phosphatase positively correlated with soil clay, and invertase with soil silt content.

Results from this study suggested that along with chemical and physical indicators, enzyme activities could be additional indicators of the degree of erosion of Chromic Luvisols. Further studies on different soil types are to be carried out. Data obtained are intended to contribute to development of biological indicators of eroded soils.

\section{References}

Acosta-Martinez, V., Cruz., L., Ramirez, D.S., Alegria, L.P., 2007. Enzyme activities as affected by soil properties and land use in a tropical watershed. Applied Soil Ecology 35(1): 35-45.

Ampova, G., Paskaleva, K., 1970. The use of Schoorl's method in determining the activity of the invetrase enzyme in soil. Soil Science and Agrochemistry 5(6): 69-72.

Arinushkina, E.V., 1975. Agrochemical Methods of Soil Analysis. Science, Moscow, Russia. 656 p.

Gülser, C., 2006. Effect of forage cropping treatments on soil structure and relationships with fractal dimensions. Geoderma 131: 33-44.

Ivanov, P., 1984. New acetate method for assessing plant available phosphorus and potassium in soil. Soil Science and Agrochemistry 19(4): 88-97.

Kachinskiy, N.A., 1958. Soil particles and micro-aggregates composition: Methods for Analysis. USSR Academy of Sciences, Moscow, Russia. 193p.

Kandeler, E., Palli, S., Stemmer, M., Gerzabek, M.H., 1999. Tillage changes microbial biomass and enzyme activities in particle-size fractions of a Haplic Chernozem. Soil Biology and Biochemistry 31(9): 1253-1264.

Kizilkaya, R., Askin, T., Ozdemir, N., 2003. Use of enzyme activities as a soil erodibility indicator. Indian Journal of Agricultural Sciences 73: 446-450.

Lal, R., 2006. Managing soils for feeding a global population of 10 billion. Journal of the Science of Food and Agriculture 86(14): 2273-2284.

Marx, M.-C., Kandeler, E., Wood, M., Wermbter, N., Jarvis, S.C., 2005. Exploring the enzymatic landscape: distribution and kinetics of hydrolytic enzymes in soil particle-size fractions. Soil Biology and Biochemistry 37(1): 35-48.

Moreno-de las Heras, M., 2009. Development of soil physical structure and biological functionality in mining spoils affected by soil erosion in a Mediterranean-Continental environment. Geoderma 149 (3-4): 249-256.

Nedyalkova, K., Donkova, R., Petkova, G., 2013. Phosphatase activity of eroded (arable and virgin) soils. Journal of Balkan Ecology 16(4): 367-373.

Özdemir, N., Öztürk, E., Durmus, O.T.K.., Ekberli, I. 2015. Effects of organic and inorganic amendments on soil erodibility. Eurasian Journal of Soil Science 4(4): 266-271.

Park, J.H., Meusburger, K., Jang, I., Kang, H., Alewell, C., 2014. Erosion-induced changes in soil biogeochemical and microbiological properties in Swiss Alpine grasslands. Soil Biology and Biochemistry 69: 382-392.

Puglisi, E., Del Re, A.A.M., Rao, M.A., Gianfreda, L., 2006. Development and validation of numerical indexes integrating enzyme activities of soils. Soil Biology and Biochemistry 38 (7): 1673-1681.

Stefanic, G., Dumitru, L., 1970. Determination de l'activite de la catalase du sol por voie colorimetrique. Biologie du Sol 12: $12-13$.

Tabatabai, M.A., 1994. Soil enzymes. In: Weaver, R.W., Angle J.S. and Bottomley P.S. (eds.). Methods of Soil Analysis: Part 2. Microbiological and Biochemical Properties, SSSA Book Ser. 5, SSSA, Madisson, WI, USA. pp.775-833.

Trasar-Cepeda, C., Leiros, M.C., Gil-Sotres, F., 2000. Biochemical properties of acid soils under climax vegetation (Atlantic oakwood) in area of the European temperate-humid zone (Galicia, NW Spain): Specific parameters. Soil Biology and Biochemistry 32: 747-755.

Yin, R., Deng, H., Wang, H.I., Zhang, B., 2014. Vegetation type affects soil enzyme activities and microbial functional diversity following re-vegetation of a severely eroded red soil in sub-tropical China. Catena 115: 96-103. 